\title{
Linguistic Culture and Essentialism in South Africa
}

\author{
Stephanie Rudwick *
}

\begin{abstract}
This paper explores how language and culture are intertwined and often regarded as "invariable fixed properties" in contemporary South Africa by focusing on one particular indigenous African language group, i.e. isiZulu-speakers. Drawing from general theoretical sociolinguistic approaches to language and culture and considering South Africa's socio-political history, the paper demonstrates the significance and saliency of Zulu linguistic culture to Zulu people in the post-apartheid state. It is examined, how Zulu linguistic culture is regarded a resource in the isiZulu-speaking community and as one of the most salient tools of in-group identification in the larger contemporary South African society. Zulu people's culture is profoundly language-embedded and Zulu linguistic culture often based on essentialism.
\end{abstract}

Key words: Linguistic culture, Zulu, essentialism

\section{Introduction}

Globalisation and increasing levels of intercultural communication have led to the emergence of more and more multilingual and hybrid linguistic cultures. In most urban centers in the world, individuals speak one or more other languages besides their mother tongue and merge certain elements of the cultural lifestyles of other people with their own. While this is so, there are also many individuals and communities who maintain, largely but not only by force, a mono-cultural and monolingual lifestyle. Inspired by German Romanticist writers, such as Herder and Humboldt ${ }^{\mathbb{D}}$, among others, there has been a widely shared ideological position that monolingualism is conducive for the preservation of a

\footnotetext{
* Stephanie Rudwick: Linguistics Programme, University of KwaZulu-Natal, Howard College Campus, Durban 4041, South Africa. E-mail: rudwicks@ukzn.ac.za. Acknowledgements: I am indebted to my many research participants in KwaZulu-Natal, South Africa, all of whose names, unfortunately, I cannot mention here. Special thanks, however, go to my assistants Nqobile Buthelesi and Nkosikhona Sikhakhane. Further thanks go to the University of KwaZulu-Natal for a generous post-doc fellowship.

(1) For a detailed summary of Humbolt's conceptualisation of the correlation between language and culture in the context of the concept of 'Weltansicht' [worldview]', see Heeschen (1977: 159-190).
} 
single, united culture and nation. More recently, however, the benefits of multilingualism and how it can be employed as a resource rather than a problem, has widely been acknowledged by language planners and policy makers. South Africa has propagated the "unity in diversity' strategy which includes a language policy that recognizes eleven languages as official. Despite this official multilingualism many individuals on a grassroots level do not necessarily support the policy or subscribe to a postmodern view which sees language, culture and identity as dynamic, multi-facetted and changeable phenomena. For many people, their own language, culture and identity are fairly static reference points which provide vital meaning for their lives. Among such people, linguistic culture is frequently essentialised, and this paper illustrates how such a dynamic manifests itself in a particular South African ethnolingustic group.

South Africa is a country with a constitution that stipulates 'language and culture' as deeply interwoven, recognizes eleven languages as official and includes several paragraphs which emphasize the right of every citizen to engage in the linguistic and cultural practices of his/her choice. Historically in South Africa, it has been the Afrikaans ${ }^{\circledR}$ community that has been referred to when language, i.e. Afrikaans, is pointed out as the foremost element of the culture of the people. While I do acknowledge that the linguistic culture of most Afrikaners is indeed characterized by great pride and an essentialized notion of the 'taal' [language, i.e. Afrikaans], the argument of this paper is directed towards another group, the speakers of the indigenous African language isiZulu. Zulu linguistic culture is often based on a unified concept rooted in essentialist thinking. Essentialism, as understood in this paper, is the belief that people and/or phenomena have an inherent and invariable 'essence'. With reference to languages, this paper regards essentialism as being based on purist and prescriptivist approaches to language. There are many puristic linguistic traditions in the world, and many linguistic cultures have gone through periods of purism as a result of a perceived threat of some other languages (Schiffman 1996: 171). Generally defined, an essentialized linguistic culture is regarded as non-dynamic and static and characterized by clear-cut criteria which are perceived as unchangeable. Although I acknowledge that the notion of 'linguistic culture' in itself is problematic for culture critics, I argue in line with Schiffman (1996: 9) that it is indispensable to describe certain sociolinguistic dynamics.

\footnotetext{
(1) Although Afrikaans is spoken primarily by white people of Dutch descent, the language must be considered an indigenous language in contemporary South Africa, as it emerged in this country and is native to it.
} 


\section{Linguistic Culture and Essentialism in South Africa}

\section{Socio-historical considerations}

Recent empirical research (Rudwick 2004: 159-172, 2008: 101-116) suggests that isiZulu-speakers have an extraordinary refined sense of the significance of their mother tongue, i.e. isiZulu. However, one of the main reasons why Zulu linguistic culture has not been as widely recognized as, for instance, that of the Afrikaans community, is that isiZulu did not have the historical back-up and support of the apartheid years which Afrikaans received in terms of status, corpus, acquisition planning and general development. African languages, in general, were devalued and stigmatized throughout South Africa's history (Dunjwar-Blajberg 1980). Apartheid - as a discriminatory, oppressive and manipulating political system - ascribed and prescribed inferior cultural and linguistic identities for black people. While in the post-apartheid state, many of these linguistic and ethnic ascriptions are being revised and re-evaluated in a more critical light, the link between languages and cultures prevails essentialized. ${ }^{\circledR}$ I begin the discussion of a particular South African linguistic culture by referring to the conflict-riddled and ambiguous distinction between language and dialect (Wardaugh 1996) which in South Africa offers enlightening considerations regarding the relationship between indigenous African languages, cultures and identities.

In the South African context, the term language, as distinct from dialect, is linguistically as well as socio-historically ambiguous, because what presently are different 'official' languages of the Republic of South Africa were only recently regarded as dialects belonging to particular language clusters. Mainly missionaries, but also other European colonialists, introduced the orthographies in the mid-nineteenth century and with them the linguistic distinctions between languages that could have been regarded, from a linguistic perspective, as mere varieties of one larger language family. The orthographies for these so-called 'standard' varieties of languages were, in fact, mutually intelligible (Herbert 1992, Msimang 1992). What further entrenched the separate development of these linguistic varieties was the apartheid legislation, which included the 'invention' of separate language committees for each of the nine indigenous African varieties, a process termed 'linguistic balkanisation' by Msimang (ibid.).

In more detail, Alexander (1997: 82) notes that:

\footnotetext{
(1) Sharp (1980:14), proposing an anti-essentialist, instrumentalist view, warned nearly three decades ago that South African scholars ought to put an understanding of ethnicity as a primordial phenomena aside and pay more attention to the political economy of the region and unequal distribution of power. While I acknowledge the importance of such a perspective, I focus on the views of people on the grassroots level who understand their ethnic and linguistic background in a much more simplistic essentialized way.
} 


\section{Stephanie Rudwick}

[...] even where it was possible in linguistic and political terms to allow the varieties of a particular language cluster or sub-group, such as the 'Nguni' group, to converge into a more embracing standard written form, they were systematically kept separate through lexical and other corpus-planning manoeuvres.

IsiZulu $^{(\mathbb{1}}$, the one language on focus here, is in fact a variety of the Nguni language family and can only be considered a separate language variety since the 19th century. The Nguni language family also includes isiXhosa, isiNdebele and siSwati, each with its own separate history and complex development, characterized by language contact with other languages, i.e. Khoisan, English and Afrikaans (Kamwangamalu 2001: 374). According to Msimang (1992) it is unnecessary to treat isiXhosa as distinct from isiZulu, or siSwati as different from isiNdebele, as they could well be seen as a cluster of dialects. For this reason, it is no coincidence that there have been attempts, pioneered by Nhlapo (1944) and revived by Alexander (1989, 1992), which proposed a harmonisation of the Nguni and Sotho language cluster. At Nhlapo's time (mid 20th century), when the unification of the orthographies could have still been a reality, the National Party (NP) under the leadership of Dr. Hendrik Verwoerd decided to enforce the divisive apartheid laws and created what came to be known as Bantustans or Homelands. Each ethnolinguistic group was designated a homeland, there was a Zulu homeland for isiZulu-speakers, a Xhosa homeland for isiXhosa-speaker, etc. Nonetheless, the debate on the feasibility of a possible Nguni and Sotho unification remained a contested issue for many years (Alexander 1989, 1992, Brown 1992: 71-92, Cluver 1992, Jenkins 1991: 127-134, Louw 1991). When Neville Alexander, one of the most renowned proponents of multilingualism in the country, revived the topic of harmonisation first in 1989 he suggested that for both the Sotho and the Nguni language clusters, a single written variety should be developed in order to create closer unity between the African communities.

However, not only are linguists reluctant to accept an undertaking in which seven language varieties in their own right would be reduced to two so-called 'standard' forms, most speakers of these linguistic varieties also display rather 'virulent reactions' (Mesthrie 2002: 23) and negative attitudes towards the idea. These emerge, I argue, because of the linguistic culture associated with the separate languages. Although 'harmonisation' would offer, from a practical perspective, an easier and more effective approach to the promotion

\footnotetext{
(1) There exists a multitude of dialects and varieties of isiZulu spoken in South Africa (Nubian 1991 or Zungu 1995). To distinguish these, however, is beyond the scope and quest of this paper.
} 


\section{Linguistic Culture and Essentialism in South Africa}

of indigenous African languages in the country, it has never found sufficient support for implementation for the before-mentioned reasons.

During the discriminatory apartheid education system, termed Bantu Education, the maintenance of languages and cultures were propagated and the relationship between these two variables claimed to be inextricably linked in order to justify a racist strategy. In order to succeed in the South African corporate world, proficiency in English and/or Afrikaans was [and still is] a prerequisite. Despite this fact, the speakers of the indigenous African languages were, in the past, forced to use their mother tongue as a medium of instruction up to Grade 8. By employing this strategy and a static view of the relationship between language and culture, the Nationalist government succeeded in withholding a better life from the black population and keeping them at the lower rung of the economic ladder (Herbert 1992, Makoni 1996: 261-274, Kamwangamalu 2000: 50-60). Only in the 1990s when President F.W. De Klerk announced the end of institutionalised racism and discrimination and Nelson Mandela was released from prison, did black South Africans finally have the right to participate in political discussions and were given the chance to influence the official recognition of their mother tongues. And, unsurprisingly, the issue of language has been featuring in many discussions and negotiations in the post-apartheid state.

In South Africa language has now become a terrain of struggle, a struggle over the basic human right to express oneself in one's mother tongue. It is all about self-worth and belonging and is underpinned by power: economic interest, political muscle and cultural concerns (De Klerk 1996: 8).

While a multitude of newspaper articles deal with the decline of African languages in schools and universities, it has also been claimed that the language isiZulu has been strengthening and that the "speech community in KwaZulu-Natal [...] is getting stronger because the language is now (post-apartheid era) used as an official language in government" (Mngadi 2000). There are a number of language activists who are currently promoting the development of isiZulu on all levels in the province. Furthermore, job advertisements, in particular for administrative positions do not only call for the obvious proficiency in English any longer, but also request knowledge of isiZulu. It can be argued, that from a sociolinguistic perspective, the public role and status of isiZulu has slowly but steadily improved over the past few years.

There is wide use of isiZulu on the radio, most notably Ukhozi FM, but also in TV programmes, particularly on SABC 1. The isiZulu newspaper Ilanga LaseNatali is one of the oldest newspapers in KwaZulu-Natal and the relatively new, more urban daily paper 
Isolezwe is increasingly expanding its already wide readership. On the one hand, it is generally acknowledged that isiZulu speakers have a positive attitude towards their language (Mngadi 2000), but, on the other hand, studies have shown that English is the preferred medium of instruction (MoI) in schools (e.g. Ngcobo 2000). The pertinence and weight of history must not be underestimated in this regard. Bantu Education and the before-mentioned forceful maintenance of the indigenous African languages as MoI - in a South African sociolinguistic reality in which only English and/or Afrikaans meant survival - has obviously influenced the social and political status of isiZulu. Interestingly however, and this is the main argument of the paper, more than ten years after the first democratic elections, individuals in the isiZulu-speaking community have not turned away from apartheid-based ascriptions, but affiliate strongly and in an essentialist way with traditional Zulu ethnolinguistic criteria and Zulu cultural elements. At this point, it is necessary to briefly return to the concept of 'culture' as the basis for the discussion of the concept of essentialized Zulu linguistic culture.

\section{The language-culture link re-examined}

Culture, as one of the key concepts of anthropology and intercultural communication, has been defined in a variety of ways and the last thing I would want to do here is to re-invent the wheel. ${ }^{(1)}$ Indeed, culture is, "one of the two or three most complicated words in the English language" (Williams 1983: 76) ${ }^{2}$. For the purpose of this paper it is only of interest how linguistic elements and language specific traditions are essentialized for the culture on focus here. White (1947: 686-698), one of the early anthropologists, points out the importance of language in the study of culture as it encompasses all symbolic behaviour. Accordingly, it is primarily language, that allows for the transmission of specific cultural and traditional ideas from one generation to the next. "To understand culture is to explore how meaning is produced symbolically through the signifying practices of language within material and institutional context" (Barker and Galasinski 2001: 4). Language has further been seen as "the key to the heart of culture" (Edwards 1985: 15) it is widely regarded as a symbol, a weapon, and the very medium by which particular cultural identification processes are expressed.

\footnotetext{
(1) As early as 1952, Kroeber and Kluckhohn list and survey nearly 300 definitions of the term 'culture' (Seymour -Smith 1986: 65).

(2) Extensive anthropological debates occurred in the last decades which culminated in some scholars even questioning the utility of culture as a concept. For further reading see Brightman (1995: 509-546).
} 


\section{Linguistic Culture and Essentialism in South Africa}

Thornton (1988: 24) regards culture itself as a resource but acknowledges the differences in the way people interpret their own culture which, he asserts, reflects differing access to cultural resources. Similarly, it has been argued, that "in any specific interaction, one finds only part of the group culture, and an individual carries basically a personal theory of the group culture, not necessarily a complete or static one" (Ferdman and Horenczyk 2000: 85). While the post-modern notion of culture is one that is dynamic, flexible, and a changing process of signification, people on the grassroots level often do not share this view about their own culture. For many individuals in this world, their culture consists of specific elements, and as a whole, is something that is pretty well cast in stone and perceived as reasonably homogenous.

The South African society is, in praxis, still largely segregated and the dealing with the 'other culture' often does not go beyond notions of tolerance and acceptance. Ironically, people in South Africa often seem to justify lack of understanding regarding particular events and incidents with the notion of 'cultural differences'. What these cultural differences really are and how they manifest themselves, remains often vague and unspecified. Among the many facets of culture, language is definitely one of the more stable elements and in most cases, an immediate one. In Africa, several leaders and many members of the African intelligentsia based their struggle for mental liberation from the colonial heritage on an approach based on the language-culture link (Mazrui and Mazrui 1998: 53). ${ }^{(1)}$ Ngugi wa Thiongo, (1986: 13), for instance, stresses the character of language as a carrier of culture and regards the two variables [language and culture] as inseparable on the basis of a reciprocal relationship. Language in this respect has three important aspects. Firstly, it implies that "language as culture is a product of the history which it in turn reflects" (Ngugi 1986: 15). Indeed, the South African case shows evidence of this conviction as the historical oppression of the indigenous African languages and cultures was and still is reflected in extremely low social and economic status of the languages. The second aspect of language as a carrier of culture is what Ngugi describes as "an image-forming agent in the mind of a child" (1986: 15). Accordingly, our whole conception of ourselves as people, individually and collectively, is influenced by those inherently produced and linguistically embedded pictures and images. Ngugi particularly stresses the

\footnotetext{
(1) Some African nationalists recognise a cause and effect relationship between the promotion of the African languages and decolonisation. In general, however, this approach has found little support in language policies in Africa and has been criticised for making "a fetish of language, endowing it with the power of colonisation or liberation in a manner that is a-historical, static and undialectical" (Mazrui and Mazrui 1998: 55).
} 


\section{Stephanie Rudwick}

function of the mother tongue in creating harmony in an individual's life and insists, in what is essentially the third aspect, that it is particularly the mother tongue and home language through which positive reality is transmitted (ibid.). ${ }^{(1)}$ Language, as approached by Ngugi $(1986,1993)$, is immeasurably significant as a cultural phenomenon, thus he ascribes paramount importance to what could be considered an essentialised linguistic culture. Similarly, one of the most renowned sociolinguistic scholars in the field (Fishman 1996) suggest that language is not only a part of culture, but also that "every language provides an index for the culture with which it is most intimately associated, and every language becomes symbolic of the culture with which it is most intimately associated". In this paper, I explore the linguistic associations with culture in reference to isiZulu and Zulu culture.

\section{Zulu linguistic culture}

In order to give my students an example of how inextricably the language isiZulu is linked to Zulu culture and a Zulu identity I generally refer to a lecture experience which dates back a few years. The lecture topic was 'Language and Identity in post-apartheid South Africa', a topic too broad to even cover adequately in an entire semester. As I wanted to achieve some kind of interactive environment for the approximately 300 first year students, I decided for a controversial statement in which I argued that "A person may be ethnically Zulu, in other words, have a Zulu ethnicity, but not speak isiZulu as a mother tongue". One of the immediate comments of a student was that Zulu culture could not be practiced without the knowledge of isiZulu, a comment most others seem to agree on. Overall, the virulent protest the comment had triggered can be considered a clear indicator that there is an element of essentialism in the way Zulu linguistic culture was perceived by these students.

If one takes a closer look at the sociolinguistic dynamics at work in the Zulu community, it becomes clear, that despite the socio-economic hegemony of the English language in South Africa, most isiZulu-speakers conduct their private and personal life primarily in isiZulu, albeit with variable levels of code-switching to English. In most rural and township domestic settings, ethnic affiliation and a Zulu cultural and linguistic lifestyle is evident. In

\footnotetext{
(1) Ngugi has extensively published on the issue of the domineering function of the English language on the African mind "...the most coveted place in the pyramid and in the system was only available to holders of an English-language credit card. English was the official vehicle and the magic formula to colonial élitedom" (Ngugi 1986: 115). In the late 1970s, Ngugi rejected English as a medium of expression in his writing and started to publish in Gikuyu, his mother tongue.
} 


\section{Linguistic Culture and Essentialism in South Africa}

urban settings and affluent homes, there appears to be increasing "concern about the loss of the African languages and culture" (Slabbert and Finlayson 2000: 134). The increasing use of English among some urban members in the isiZulu-speaking community functions as the catalyst for others to despise the ex-colonial language even further. Negative attitudes towards English are based on the argument that it 'destroys' isiZulu and has a negative impact on Zulu culture. Notably, sentiments of this kind are not only voiced by the older generation, but also surface among members of the youth as well (Rudwick 2006).

The social and linguistic custom of respect [hlonipha] is clearly one of the core elements of Zulu linguistic culture and 'insider' accounts (see, for instance, Dlamini 2005) of Zulu culture and identity politics never fail to refer to hlonipha as one of the cornerstones of 'Zuluness'. In fact, ukuhlonipha [to show respect] includes a specific language variety, known as isiHlonipho [the language of respect]. In its most 'proper' sense, isiHlonipho is primarily practiced by women as the avoidance of the usage of syllables occurring in the names of relatives of older and/or superior status and in reference to the names of ancestors. In his pioneering thesis, Mcube (1949) argues that oral hlonipha is essentially the 'speech of women', because 'all women among the Nguni are, at a certain stage of their lives required by custom to use the hlonipha vocabulary'. This linguistic practice, although no longer used in its strict traditional variety in urban areas, still carries noteworthy significance among Zulu people, not only females (see Zungu 1995 and Rudwick and Shange 2006: 473-482). The avoidance of the names of male relatives and ancestors is still common practice among Zulu speakers, both male and female. While the traditional variety of the linguistic custom of isiHlonipho is still upheld in many rural areas of the province KwaZulu-Natal, for instance, many urban Zulu people practice a hlonipha linguistic culture which could be regarded the 'soft' variety of the original one. Its significance nonetheless prevails. Dlamini (2001: 206) notes that "in Zulu households, children are brought up with a strong emphasis on ukuhlonipa abadala [respect for adults] and a non-confrontational way of disagreeing with adults". There is no doubt that ukuhlonipha is still part and parcel of social and linguistic etiquette in contemporary Zulu society, particularly in rural areas.

The usage of the English language and hlonipha as respectful behaviour is widely seen as contradictory. Many Zulu parents and elders perceive it as highly disrespectful for children to speak to them in English. According to them the language does not provide sufficient respect. Hence, the youth often carefully refrains from code-switching into English among older and rural Zulu relatives. It is frequently believed that there exists a discrepancy between the Zulu value system and English language expressional power. In 
particular, older people in the Zulu community bemoan the decreasing value of ukuhlonipha [respect] in the context of excessive usage of the English language. (Rudwick $2006: 193)$

Additionally to ukuhlonipha there are further elements in the Zulu linguistic culture which must be considered essential parts of the social system of the community. The reciting of folk-tales and legends and the poetry of songs and praises are an important constituent of Zulu culture. Indeed, the significance of izibongo [praise-poems] is noteworthy. They are profoundly embedded in Zulu linguistic culture. Izibongo reflect not only the background of Zulu social life but also of the country (Cope 1968: 17). Praises play an all-encompassing role in the cultural and linguistic life of Zulu people. Not only amadlosi [ancestors] who are worshipped are given praise names but any individual in Zulu society may be given a praise name. In traditional Zulu society, parents give their children praises, children who are in the same intanga [age group] give praises to each other and young men of the same ibutho [age-set] or impi [regiment] give praise names to each other (Cope 1968: 21). Praise-poems are the expression of general public opinion and their function is to bring conformity to approved modes of behavior and provide social control in the society.

Furthermore, isiZulu is a language rich in proverbs and idioms which all have profound cultural significance. Many of them provide insight into the collectivist nature of Zulu society and indicate what kind of social characteristics are important for a respectable Zulu person. Much of Africa's history has been passed on orally and one consequence of this is that cultural wisdom is best expressed in the form of proverbs. Nyembezi (1990) published an entire monograph on Zulu proverbs which has been widely referred to by isiZulu scholars and researchers. The knowledge of proverbs and a well-articulated, eloquent and effective isiZulu speech is highly regarded and a cultural achievement among Zulu people. Zulu proverbs always carry a certain moral codex and while many proverbs are no longer known by the young generation of isiZulu-speakers, they are still acknowledged for the symbolic value and seen as a significant aspect of Zulu culture. Most recently, Makhanya (2008: 38) refers to the legend of intshebe yaKwaMashu which spawned a famous Zulu proverb saying Wakhala ngaphansi njengentshebe yaKwaMashu [you fell like the bearded on of KwaMashu]. In isiZulu this proverb has deep meaning and is used to illustrate missed opportunities or occasions. Zulu custodians and stake-holders of culture and tradition maintain to make usage of proverbs in their speeches.

Further evidence for the vitality and essentialized significance of isiZulu for the culture 


\section{Linguistic Culture and Essentialism in South Africa}

and identity of Zulu people is that, in general, isiZulu-speakers are frequently reluctant to accommodate speakers of other African languages (Slabbert and Finlayson 2000: 132). The use of the mother tongue is a sign of distinction that in-group members demonstrate in order to show that language is a significant component of their cultural identity. IsiZulu-speakers are well-known for their reluctance to learn other indigenous African languages. IsiZulu is perceived as a cultural resource and represents a cultural symbol that is not only treasured significantly in the community, but one that also transcends boundaries created by other cultural elements. Most Zulu people have an extraordinarily refined and essentialized sense of what it means 'to be' or 'not to be' Zulu. What I argue here, is that knowledge of the language, i.e. isiZulu, is one, or perhaps 'the' least disputed constituent of Zulu culture and ethnicity. For many isiZulu-speakers, in particular in rural areas of South Africa, the adoption of English as the primary means of communication is not acceptable for a 'self-respecting Zulu'.

Furthermore, a 'native-like' English accent with no trace of a Zulu background is often observed with a skeptical eye by many Zulu people, to the extent that some, who have been educated in exile or so-called 'white' schools and speak immaculate Standard English, would purposely add a Zulu-English accent to their speech in order to appear less elitist. The Zulu-English variety has a marked ethnic component, both grammatically and phonologically. It has been argued recently that some Zulu people claim that to speak English like a native speaker is not desirable for what is considered a 'true' Zulu person (Rudwick 2008: 111). Derogatory terms such as "coconut" (or "oreo") ${ }^{(1)}$ reflect a "white' and 'western' lifestyle, which, of course, includes English. While it needs to be acknowledged that, in urban centers of South Africa, English is becoming more and more dominant and intruding the family domain in many affluent African homes, Zulu people who choose English as their primary means of expression are still rare. For the vast majority of Zulu people in the country isiZulu remains an essential constituent of who they are. Zulu people who are no longer capable of speaking their language as a native speaker ${ }^{2}$

\footnotetext{
(1) In South Africa, the usage of the term "coconut" implies that, although a black person has dark skin on the outside, she/he is "white" inside, just as a coconut's shell is dark and the flesh inside is white. "Oreo" has an equivalent meaning, but the terms origin is the trademark name of a type of sandwich cookie, popular in the United States, that has two chocolate layers filled by white frosting (Rudwick 2008: 102). Although both labels are used in South Africa, "coconut" is more common. For more detail on 'coconut-dynamics', see Rudwick 2008.

(2) There are cases where isiZulu speakers had been living overseas for many years, e.g. in Great Britain or the United States and when returning to their home country realized that they don't really 'fit in' because their dominant language is English.
} 


\section{Stephanie Rudwick}

are looked down upon by the larger community.

All these constituents of Zulu linguistic culture have an element of purism, as language practitioners and Zulu scholars guard the standard variety of the Zulu language which is employed in hlonipha customs, in the usage of izibongo and proverbs and other linguistically embedded cultural customs. Although there are many urban mixed codes and code-switching varieties which deviate from standard Zulu in quite drastic forms, many isiZulu-speakers have a strong tendency to maintain the language as 'pure' and as 'authentic' as possible.

\section{Conclusion}

Referring to speakers of Afrikaans, Kembo-Sure and Webb (2000: 122) argue that "the link between language and culture (or cultural identity) is sometimes perceived to be very direct". Indeed, the Pan South African Language Board (PanSALB), which is the 'watchdog' over language policy issues in South Africa, has received more complaints about the diminution of Afrikaans from Afrikaners than from any other language community in South Africa since the establishment of the 11-official language policy. The reason for this, however, is obvious. In apartheid South Africa, Afrikaans was, besides English, the only official and economically viable language for more than three-quarters of a century. In contrast, African language speakers grew up for generations with the knowledge that the only escape from poverty was proficiency in either English and/or Afrikaans. The indigenous African languages, e.g. isiZulu, were devalued and marginalized through discriminatory political strategies. This paper demonstrates that language, i.e. isiZulu, is no less important to Zulu people than Afrikaans is to Afrikaners. However, the weight of history overshadows the significance and pride Zulu people ascribe their language. What I have argued in this paper is that Zulu linguistic culture is rich and of paramount importance in the life experience of Zulu people. To claim Zulu cultural identity and ethnicity but not speak isiZulu prevails to be an oxymoron for most Zulu people in the post-apartheid state. Fishman (1999: 445) argues that in some instances "the language is the culture". This comment is very apt for the Zulu community where it has been argued that Zulu people have language-embedded or linguistically grounded ethnic identities (Rudwick 2006).

Part of essentialist positions is the consideration of certain social, cultural or linguistic characteristics as fixed traits that are cast in stone and immutable. It is one kind of a primordial approach which suggests that people are born with a certain identity that 


\section{Linguistic Culture and Essentialism in South Africa}

includes $\mathrm{x}, \mathrm{y}, \mathrm{z}$ characteristics and there is no variation and idiosyncracy that distinguish one individual from another. The essence implies permanence and inalterability and, at the same time, opposes cultural change. Zulu culture is saturated with essentialist modes of thinking, as 'to be Zulu' is associated with certain cultural and linguistic traits which allow for very little variation. It is important to note that an essentialist position is potentially socio-politically dangerous. It can be misused to promote mono-culturalism and trigger prejudice and discrimination towards 'less pure' and more hybrid individuals. While this paper is not evaluative and only portrays an essentialist position from a group of South African people, I raise the danger of essentialism with great concern and urge scholars to provide critical exploration of South African essentialism elsewhere. As a concluding remark, Kenneh's (1998: 36) words that "both language and culture are the blueprints of identity and value for a nation or a people" shall be echoed due to its relevance to the Zulu nation. From a sociopolitical perspective, however, variation and diversity between the languages and the cultures of the people shall be treasured, even if they are based on hybridity.

\section{References}

Alexander, Neville. 1989. Language Policy and National Unity in South Africa Azania. [M] Cape Town: Buchu.

Alexander, Neville. 1992. Harmonising Nguni and Sotho. [A] In N. Crawhall (ed.): Democratically Speaking: International Perspectives on Language Planning. [C] Cape Town: National Language Project.

Alexander, Neville. 1997. Language policy and planning in the New South Africa. [J] African Sociological Review. Vol. 1 (1).

Barker, Chris \& David Galasinski. 2001. Cultural Studies and Discourse Analysis. A Dialogue on Language and Identity. [M] London: Sage.

Brightman, Robert. 1995. Forget culture. Replacement, transcendence, relexification. [J] Cultural Anthropology. Vol. 10.

Brown, David. 1992. Language and social history in South Africa: A task still to be undertaken. [A] In K. Herbert (ed.): Language and Society in Africa,Theory and Practice of Sociolinguistics. [C] Johannesburg: Witwatersrand University Press.

Cluver, August. 1992. Language planning models for a post-apartheid South Africa. [J] Language Problems and Language Planning. Vol. 16 (2).

Cope, Trevor. 1968. Izibongo. Zulu Praise Poems. [M] Oxford: Clarendon Press.

De Klerk, Vivian. 1996. Introduction. [A] In V. De Klerk (ed.): Focus on South Africa. [C] Amsterdam/ Philadelphia: John Benjamins.

Dlamini, Sibusiswe Nombuso. 2001. The construction, meaning and negotiation of ethnic identities in KwaZulu-Natal. [A] In A. Zegeye (ed.): Social Identities in the New South Africa. [C] Cape Town: Kwela.

Dlamini, Sibusiswe Nombuso. 2005. Youth and Identity Politics in South Africa, 1990-1994. [M] Toronto: University of Toronto press.

Dunjwar-Blajberg, Jennifer. 1980. Sprache und Politik in Südafrika. Stellung und Funktion der Sprachen unter dem Apartheidsystem. [M] Bonn: Informationsstelle für südliches Afrika. 


\section{Stephanie Rudwick}

Edwards, John. 1985. Language, Society and Identity. [M] London: Basil Blackwell.

Ferdman, Bernardo M., Gabriel Horenczyk. 2000. Cultural identity and immigration: Reconstructing the group during cultural transition. [A] In E. Olshtain and G. Horenczyk (eds.): Language, Identity and Immigration. [C] Jerusalem: Hebrew Magnes University Press.

Fishman, Joshua A. 1996. What do you lose when you lose your language? [A] In G. Cantoni (ed.): Stabilizing Indigenous Languages. [C] Flagstaff: Center for Excellence in Education, Northern Arizona University.

Fishman, Joshua A. 1999. Concluding comments. [A] In J. Fishman (ed.): Handbook of Language and Ethnic Identity. [C] Oxford: Oxford University Press.

Heeschen, Volker. 1977. Weltansicht-Reflexionen. Über einen Begriff Wilhelm von Humboldts. [J] Historiographia Linguistica. No. 4. Amsterdam: John Benjamins.

Herbert, Rovert K. 1992. Language and Society in Africa. The Theory and practice of Sociolinguistics. [M] Johannesburg: Witwatersrand University Press.

Jenkins, Elwyn R. 1991. Language planning in South Africa. A discussion paper of the English Academy in Southern Africa. [J] The English Academy Report. No. 8.

Kamwangamalu, Nkonko M. 2000. A new language policy, old language practices: status planning for African languages in a multilingual South Africa. [J] South African Journal of African Languages. Vol. 20 (1).

Kamwangamalu, Nkonko M. 2001. The language planning situation in South Africa. [M] Current Issues in Language Planning 2/4.

Kembo, Sure and Webb, Vic. 2000. Languages in competition. [A] In V. Webb and Kembo-Sure (eds.): African Voices. An Introduction to the Languages and Linguistics of Africa. [C] Cape Town: Oxford University Press.

Kenneh, Kadiatu. 1998. African Identities. [M] London: Routledge.

Louw, Eric P. 1991. Issues raised by Alexander's: 'Language Policy and national unity in South Africa/Azania'. [J] Language Projects Review. No. 4/3.

Makhanya, Mondli. 2008. A future without your language is a past of wisdom thrown away. [A] Sunday Times. November 23, South Africa.

Makoni, Sinfree B. 1996. Language and identities in Southern Africa. [A] In L. de la Gorgendiere, K. King and S. Vaughan (eds.): Ethnicity in Africa. Roots, Meanings and Implications. [C] Edinburgh: Centre of African Studies, University of Edinburgh.

Mazrui, Ali A. and Mazrui, Alamin M. 1998. The Power of Babel. Language and Governance in the African Experience. [M] Oxford: James Curry.

Mcube, Fred. S. 1949. Hlonipha Language as Found among Zulu-Xhosa Women. [D] Masters Thesis, University of the Witwatersrand.

Mesthrie, Rajend. 2002. South Africa: A sociolinguistic overview. [A] In R. Mesthrie (ed.): Language in South Africa. [C] Cambridge: Cambridge University Press.

Mngadi, Buyisiwe P. 2000. UNESCO World Languages Survey. [R] Pretoria: Department of Arts, Culture, Science and Technology.

Msimang, Christian. T. 1992. African languages and language planning in South Africa (the NhlapoAlexander notion of harmonisation revisited). [M] Pretoria: BARD Publisher.

Ngcobo, Sandiso. 2000. IsiZulu-speaking educators' attitude towards the role of isiZulu in education in Durban. [D] Unpublished MA half-thesis submitted at the University of Natal, Durban.

Ngugi, wa Thiong'o. 1986. Decolonising the Mind. The Politics of Language in African Literature. [M] London: James Curry.

Ngugi, wa Thiong'o. 1993. Moving the Centre: The Struggle for Cultural Freedoms. [M] London: James Curry.

Nhlapo, Jacob M. 1944. Bantu Babel: Will the Bantu Languages live? [M] Cape Town: African Bookman.

Nubian, Sibongile E. 1991. A Survey of the Northern Zululand Dialects in the Ingwavuma Distrinct. [D] Unpublished M.A. thesis submitted at the University of Natal, Durban.

Nyembezi, Sibusiso, C.L. 1990 . Zulu Proverbs. [M] Kinderhook, N.Y.: International Book Distributors.

Rudwick, Stephanie. 2004. 'Zulu - we need [it] for our culture': The Umlazi Township youth. [J] South 


\section{Linguistic Culture and Essentialism in South Africa}

African Linguistics and Applied Language Studies. Vol. 22 (3\&4).

Rudwick, Stephanie. 2006. Language, identity and ethnicity in post-apartheid South Africa: the case of the isiZulu-speaking community. [D] PhD thesis, University of KwaZulu-Natal.

Rudwick, Stephanie, Magcino Shange. 2006. "Sociolinguistic oppression or expression of 'Zuluness'? 'IsiHlonipho' among isiZulu-speaking females. [J] South African Linguistics and Applied Language Studies. Vol. 24 (4).

Rudwick, Stephanie. 2008. Coconuts and Oreos: English-speaking Zulu people in a South African township? [J] World Englishes. Vol. 27 (1).

Seymour-Smith, Charlotte. 1986. Macmillian Dictionary of Anthropology. [M] London: Macmillian Press.

Sharp, John. 1980. Can we study ethnicity? A critique of fields of study in South African anthropology. [J] Social Dynamics. Vol. 6 (1).

Schiffman, Harold. 1996. Linguistic Culture and Language Policy. [M] London: Routledge

Slabbert, Sarah, Rosalie Finlayson. 2000. 'I'm a cleva!': Linguistic makeup of identity in a South African urban environment. [J] International Journal of the Sociology of Language. Vol. 144.

Thornton, Robert. 1988. Culture: A contemporary definition. [A] In E. Boonzaier and J. Sharp (eds.): South African Keywords. [C] Cape Town/Johannesburg: David Philip.

Wardaugh, Ronald. 1996. An Introduction to Sociolinguistics. [M] Oxford/Cambridge: Blackwell.

White, Leslie A. 1947. Culturological versus psychological interpretations of human behaviour. [J] American Sociological Review. No 12.

Williams, Raymond. 1983. Keywords. A Vocabulary of Culture and Society. [M] London: Fontana.

Zungu, Phillis J. 1995. Language Variation in Zulu: A Case Study of Contemporary Codes and Registers in the Greater Durban Area. [D] Unpublished PhD thesis submitted at the University of DurbanWestville. 